\title{
Design of a transportation system for workers in a Cuban resort area
}

\author{
J. Muñuzuri, L. Onieva, P. Cortés \& J. Guadix \\ School of Engineering, University of Seville, Spain
}

\begin{abstract}
The objective of our work is to solve the problem of transferring workers from a resort set on two cays (islets sandy) in the Sabana-Camaguey archipelago, north of Cuba, from their home areas to the resort and vice versa. We start with an economic analysis of the possible alternatives to solve the problem. Those that result most favorable economically are then subject to an environmental analysis, for tourism development in the area is based on the physical environment of high ecological and landscape that surrounds it. After completing the environmental impact study of each alternative, we choose the most appropriate and favorable one. In the case of the introduction of a means to transport workers, we proposed light rail as the most economically feasible option, due to the conditions of our problem. Finally, we arranged the transfer of workers using buses from the terminal to the various hotels in the resort area.
\end{abstract}

Keywords: transportation, workers, sustainability, optimisation.

\section{Introduction}

Jardines del Rey is a resort area composed of cayos (islands linked to the mainland by a narrow road bridge or pedraplen), of recent and increasing development. As shown in Figure 1, it is located in the Sabana-Camaguey archipelago, north of the Cuban province of Ciego de Ávila, some 300 miles east of Havana and just 3 miles from the southern edge of the Old Bahamas Canal, a major international maritime corridor. The area, ranked the third largest and second in beach length of Cuba, is becoming one of the strongest tourist destinations in the region. The main cayos in Jardines del Rey, and the ones where the resort activity is concentrated, are Cayo Coco and Cayo Guillermo. Cayo Coco, the largest one, contains the international airport, and is linked to Turiguano, in the province of Ciego de Ávila, by a $17 \mathrm{~km}$ pedraplen, and to Cayo Guillermo by a smaller one. 


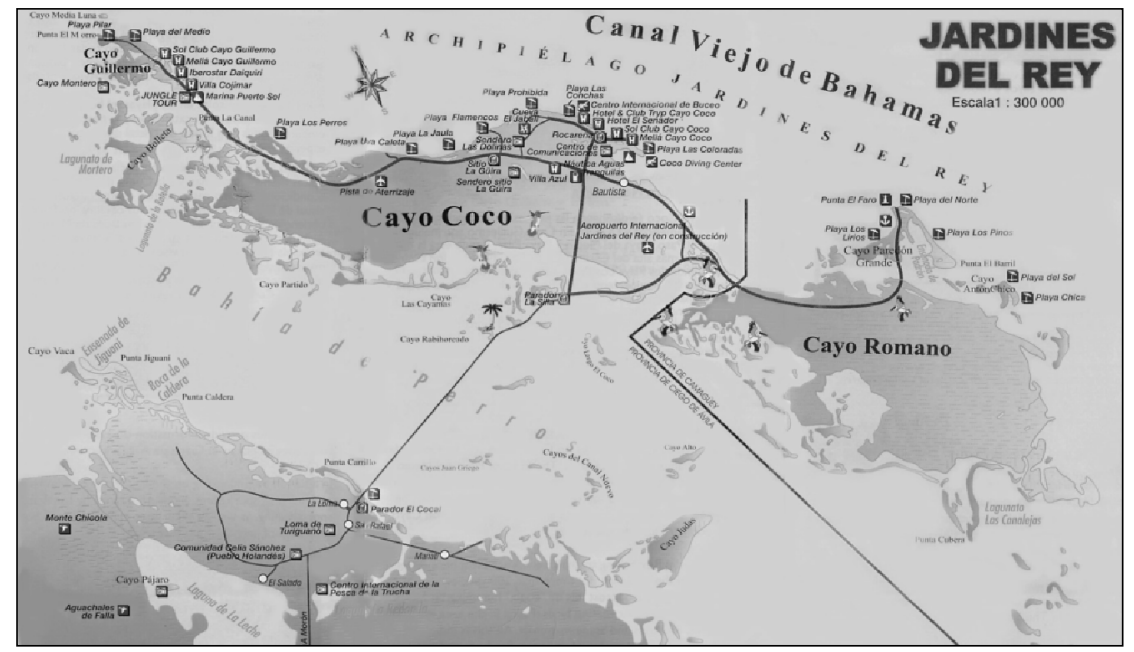

Figure 1: Main islands in the Jardines del Rey area (source: cuba-junky.com).

The only buildings in Jardines del Rey correspond to hotel and resort premises, which means that there are no resident towns in the area. Hotel workers live in the mainland, in the Ciego de Avila province, in towns like Ciego de Ávila, Morón, Ciro Redondo, Ceballos, etc., and need to be commuted to the hotels every day.

The current transportation system is organized with buses, operating from the towns of Ciego de Ávila and Morón (see Figure 2 for the distances between the main nodes in the transportation graph, and Table 1 for the description of the buses included in the current transportation fleet). These buses, which are only used for the cayos service, are provided by the Cuban government, and the hotels pay an annual fee for the service. Tourists use a different type of buses, driving on the same roads, which are in a rather bad state of conservation. They are designed for a speed of $100 \mathrm{~km} / \mathrm{h}$, but because of their state the actual speed of buses does not exceed an average $60 \mathrm{~km} / \mathrm{h}$. The existing transport infrastructure manages to cover the current needs for transportation, but the expected growth in the area is more than likely to saturate it in the near future.

Table 1: $\quad$ Current bus fleet used in the transportation system.

\begin{tabular}{|c|c|}
\hline Bus capacity & No of available buses \\
\hline 6 & 52 \\
\hline 70 & 45 \\
\hline 19 & 33 \\
\hline 2 & 30 \\
\hline
\end{tabular}

As a continuation of the economic analysis that we completed in a previous research work [1], our objective here is to assess the selected mobility solution (light rail) from an environmental point of view, which is not a negligible one given the natural and landscape richness of the Jardines del Rey area. 


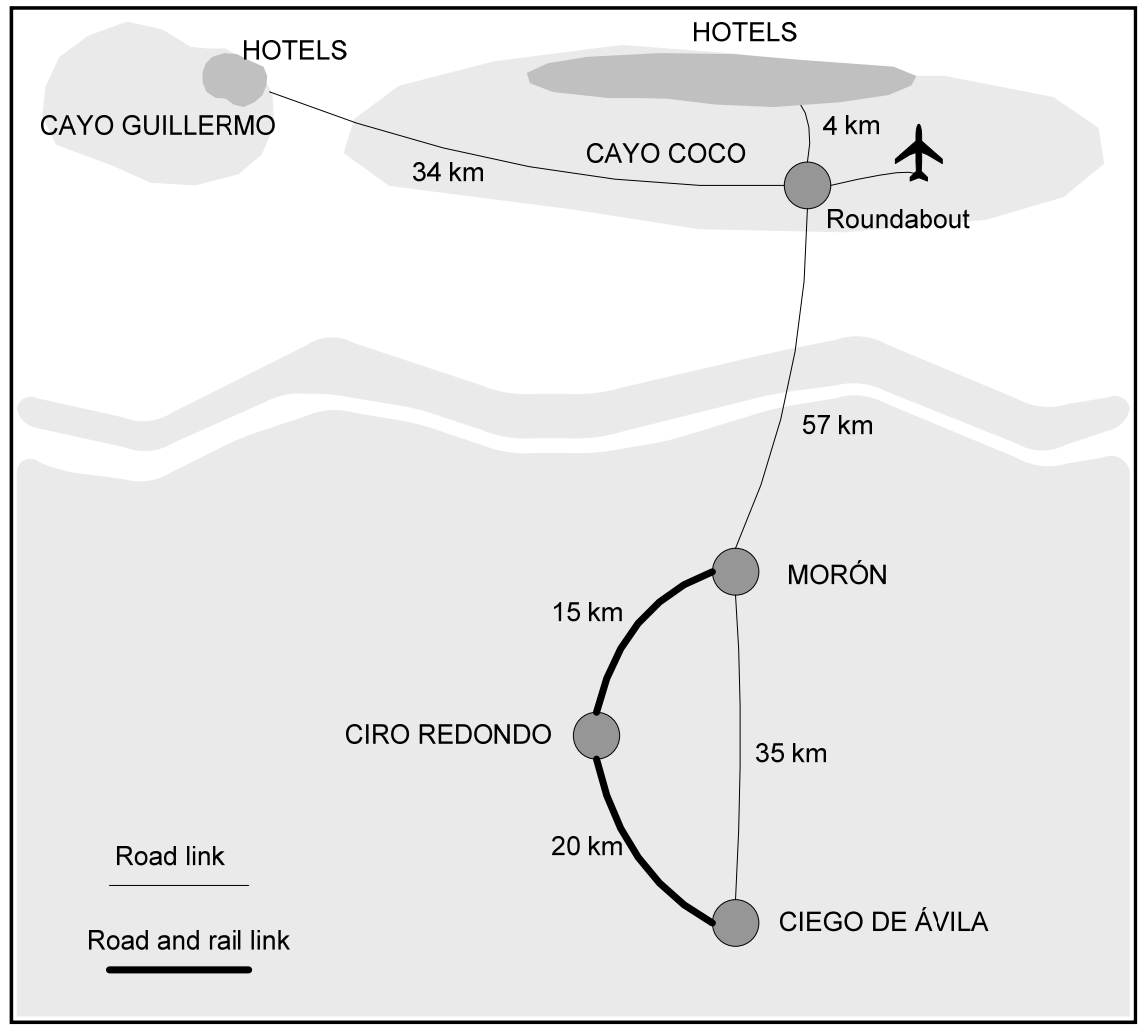

Figure 2: Schematic representation of the area, with the towns of Morón, Ciro Redondo and Ciego de Ávila in the mainland and the hotel areas of Cayo Coco and Cayo Guillermo.

\section{Description of the mobility problem}

The Jardines del Rey hotels are visited by 320,000-350,000 tourists every year. Current data (year 2010) shows a total amount of 4,000-5,000 hotel rooms in Cayo Coco and Cayo Guillermo, requiring some 3,700 workers per day. Furthermore, the current growth rate of the area should result in a $100 \%$ increase by 2020 , which represents 765,000 tourists per year, 12,400 hotel rooms and more than 8,000 hotel workers. This are a daily averages of data for the whole year, but the numbers of tourists and workers are very different in high and low seasons.

In the current scenario, workers need to arrive at the hotels in three different shifts $(6: 30,8: 00$ and 14:30), and also have three different return times (16:30, 18:00 and 24:00). To provide an overall picture of the mobility problem, Table 2 shows the number of workers that need to arrive at each destination in each one of the shifts, and Table 3 shows the number of workers that go back. 
Table 2: $\quad$ Number of workers arriving at each destination in the cayos in the morning.

\begin{tabular}{|c|c|c|c|c|c|c|c|c|c|c|}
\hline \multirow{2}{*}{$\begin{array}{c}\text { Morning } \\
\text { (mainland to cayos) }\end{array}$} & \multicolumn{8}{|c|}{ Low season } & \multicolumn{1}{|c|}{ Medium season } & \multicolumn{3}{|c|}{ High season } \\
\hline & Destination & $\mathbf{6 : 3 0}$ & $\mathbf{8 : 0 0}$ & $\mathbf{1 4 : 3 0}$ & $\mathbf{6 : 3 0}$ & $\mathbf{8 : 0 0}$ & $\mathbf{1 4 : 3 0}$ & $\mathbf{6 : 3 0}$ & $\mathbf{8 : 0 0}$ & $\mathbf{1 4 : 3 0}$ \\
\hline $\mathbf{1}$ & H. Sol Meliá Coco & 111 & 182 & 177 & 133 & 219 & 200 & 160 & 261 & 238 \\
\hline $\mathbf{2}$ & H. Senador & 179 & 57 & 158 & 216 & 69 & 188 & 258 & 83 & 223 \\
\hline $\mathbf{3}$ & H. Tryp & 125 & 143 & 93 & 149 & 172 & 111 & 177 & 205 & 134 \\
\hline $\mathbf{4}$ & H. Playa Coco & 61 & 132 & 94 & 74 & 158 & 114 & 89 & 188 & 137 \\
\hline $\mathbf{5}$ & H. Sol Guillermo & 35 & 37 & 28 & 42 & 45 & 33 & 50 & 54 & 39 \\
\hline $\mathbf{6}$ & H. Melián Guillermo & 25 & 33 & 33 & 30 & 40 & 40 & 36 & 48 & 48 \\
\hline $\mathbf{7}$ & Villa Cojimar & 33 & & & 40 & & & 48 & & \\
\hline $\mathbf{8}$ & H. Iberostar Daiquiri & 37 & & 35 & 44 & & 42 & 52 & & 50 \\
\hline $\mathbf{9}$ & H. Blau Colonial & 101 & 72 & 111 & 122 & 87 & 135 & 146 & 103 & 162 \\
\hline $\mathbf{1 0}$ & Non-hotel & 68 & 72 & & 81 & 86 & & 96 & 102 & \\
\hline $\mathbf{1 1}$ & Ruteros Guillermo & 128 & 40 & 69 & 153 & 48 & 84 & 182 & 57 & 101 \\
\hline $\mathbf{1 2}$ & Airport & & 99 & & & 120 & & & 144 & \\
\hline $\mathbf{1 3}$ & Customs office & & 94 & & & 113 & & & 135 & \\
\hline $\mathbf{1 4}$ & Cubacanán & 33 & & & 40 & & & 48 & & \\
\hline $\mathbf{1 5}$ & Marina Port & & 33 & & & 40 & & & 48 & \\
\hline $\mathbf{1 6}$ & Caracol & & 42 & & & 50 & & & 62 & \\
\hline $\mathbf{1 7}$ & Others Cayo Coco & 35 & 192 & & 42 & 233 & & 50 & 280 & \\
\hline & TOTAL & 971 & 1228 & 798 & 1166 & 1480 & 947 & 1392 & 1770 & 1132 \\
\hline
\end{tabular}

Table 3: Number of workers leaving each destination in the cayos in the evening.

\begin{tabular}{|c|c|c|c|c|c|c|c|c|c|c|}
\hline \multirow{2}{*}{\multicolumn{2}{|c|}{\begin{tabular}{|c|} 
Evening \\
(cayos to mainland) \\
\end{tabular}}} & \multicolumn{9}{|c|}{ Number of workers } \\
\hline & & \multicolumn{3}{|c|}{ Low season } & \multicolumn{3}{|c|}{ Medium season } & \multicolumn{3}{|c|}{ Low season } \\
\hline & Destination & $16: 30$ & 18:00 & $24: 00$ & $16: 30$ & $18: 00$ & $24: 00$ & $16: 30$ & $18: 00$ & $24: 00$ \\
\hline 1 & H. Sol Meliá Coco & 74 & 182 & 177 & 88 & 219 & 200 & 106 & 261 & 238 \\
\hline 2 & H. Senador & 204 & 32 & 158 & 246 & 39 & 188 & 294 & 47 & 223 \\
\hline 3 & H. Tryp & 97 & 134 & 93 & 116 & 161 & 111 & 140 & 192 & 134 \\
\hline 4 & H. Playa Coco & 61 & 107 & 94 & 74 & 128 & 114 & 89 & 152 & 137 \\
\hline 5 & H. Sol Guillermo & 35 & 37 & 28 & 42 & 45 & 33 & 50 & 54 & 39 \\
\hline 6 & H. Meliá Guillermo & 25 & 33 & 33 & 30 & 40 & 40 & 36 & 48 & 48 \\
\hline 7 & Villa Cojimar & 33 & & & 40 & & & 48 & & \\
\hline 8 & H. Iberostar Daiquiri & 37 & & 35 & 44 & & 42 & 52 & & 50 \\
\hline 9 & H. Blau Colonial & 101 & 72 & 74 & 122 & 87 & 90 & 146 & 103 & 108 \\
\hline 10 & Non-hotel & 40 & 100 & & 48 & 119 & & 57 & 141 & \\
\hline 11 & Ruteros Guillermo & 128 & 40 & 69 & 153 & 48 & 84 & 182 & 57 & 101 \\
\hline 12 & Airport & 99 & & & 120 & & & 144 & & \\
\hline 13 & Customs office & 94 & & & 113 & & & 135 & & \\
\hline 14 & Cubacanán & 33 & & & 40 & & & 48 & & \\
\hline 15 & Marina Port & 33 & & & 40 & & & 48 & & \\
\hline 16 & Caracol & & 25 & & & 30 & & & 36 & \\
\hline 17 & Others Cayo Coco & 33 & 194 & & 40 & 235 & & 48 & 282 & \\
\hline & TOTAL & 1127 & 956 & 761 & 1356 & 1151 & 902 & 1623 & 1373 & 1078 \\
\hline
\end{tabular}




\section{Light rail system}

The choice of a light rail system to transport workers to the hotel, which could also be used to transport tourists to the mainland for one-day visits, was economically justified in [1]. Light rail allows for steeper slopes and smaller turning radiuses than conventional rail systems, and also presents lower entry/exit times for passengers due to its low platform. The rail system would use the existing railroad infrastructure (see Figure 2), extending it to the main roundabout in Cayo Coco.

Given the current data shown in Tables 2 and 3, the commuter demand could be covered using only two trains, each one of them doing two return trips per day, with the schedules shown in Table 4. The trains would be based in Ciego de Ávila and travel to Ciro Redondo, Morón, Cayo Coco and back. The difference between this scheme and the 150 buses currently used is evident, given also the significant reduction in travel times.

Table 4: $\quad$ Proposed schedules for the light trains between Ciego de Ávila and Cayo Coco.

\begin{tabular}{|c|c|c|}
\hline Train & C. de Ávila-Cayo Coco & Cayo Coco-C. de Ávila \\
\hline A & $6: 30-8: 00$ & $13: 00-14: 30$ \\
\hline & $14: 30-16: 00$ & $18: 00-19: 30$ \\
\hline B & $8: 00-9: 30$ & $16: 30-18: 00$ \\
\hline & $22: 30-24: 00$ & $24: 00-1: 30$ \\
\hline
\end{tabular}

\section{Environmental impacts of the light rail scheme}

Our concern was then to evaluate the light rail system from an environmental point of view, given the need for sustainable policies that help preserve the cayos as much as possible in their original state. In the first place, it is important to note that the energy consumption per person and per $\mathrm{km}$. is 3.4 times higher in buses than in light rail systems, while the capacity of the light train is around 2.3 times higher $[2,3]$. Besides, the emissions generated by the light rail system are not concentrated in the cayos, but in the electric plant, where they can be dealt with in a much more efficient way.

We therefore concentrated on the environmental impact analysis of the light rail system. We did this by in the first place identifying the relevant impacts of the system implementation in the environment. We then evaluated the significance of each phase of the project on each environmental factor, and estimated its severity using the available data.

\subsection{Identification matrix}

We chose the Identification Matrix [4] as the method to analyze impacts. This matrix (see Table 4) considers all the possible pairs between project actions and 
environmental elements. Every row corresponds to a project action (primary impact generator), and every column to an environmental aspect which may, or may not, be affected by the different actions. Each cell in the table indicates whether the environmental aspect is affected by the corresponding action, and also the gravity of the effect.

Table 4: Identification Matrix between project actions and environmental aspects (A: severe impact; B: medium impact; C: light impact).

\begin{tabular}{|c|c|c|c|c|c|c|c|c|c|c|c|c|}
\hline \multicolumn{2}{|c|}{$\begin{array}{l}\text { PROJECT } \\
\text { ACTION }\end{array}$} & 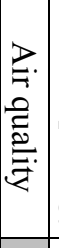 & \multicolumn{2}{|c|}{ 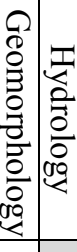 } & है & 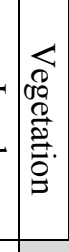 & \multirow[t]{2}{*}{ 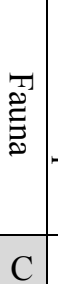 } & \multirow[t]{2}{*}{ 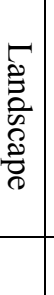 } & \multirow[t]{2}{*}{ 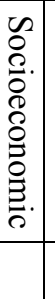 } & \multirow[t]{2}{*}{ 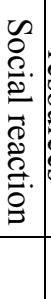 } & & 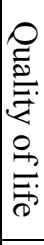 \\
\hline \multirow{7}{*}{ 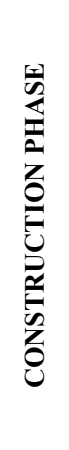 } & Powder emissions & B & & $\mathrm{C}$ & & $\mathrm{C}$ & & & & & & \\
\hline & Pollutant emissions & B & & $\mathrm{B}$ & & $\mathrm{B}$ & A & & & $\mathrm{C}$ & B & $\mathrm{C}$ \\
\hline & Noise & & & & & & B & & & $\mathrm{C}$ & B & B \\
\hline & Earth movement & & A & & $\mathrm{B}$ & B & & $\mathrm{A}$ & & $\mathrm{C}$ & & \\
\hline & Waste disposal & & & B & & $\mathrm{B}$ & B & A & & $\mathrm{C}$ & & C \\
\hline & Truck movement & & & & $\mathrm{C}$ & & & $\mathrm{C}$ & & & & \\
\hline & Spatial occupation & & & & $\mathrm{C}$ & & & $\mathrm{C}$ & & & & \\
\hline \multirow{6}{*}{ 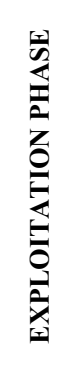 } & Acoustic emissions & & & & & & A & & & $\mathrm{C}$ & $\mathrm{A}$ & B \\
\hline & Pollutant emissions & A & & & & $\mathrm{A}$ & B & & & $\mathrm{C}$ & A & B \\
\hline & Water runoff & & & A & $\mathrm{C}$ & $\mathrm{C}$ & & & & & $\mathrm{C}$ & \\
\hline & Lane reduction & & & & & & & & & & $\mathrm{C}$ & $\mathrm{C}$ \\
\hline & Transportation of persons & & & & & & & & A & A & B & B \\
\hline & Vehicle movement & & & & & & & $\mathrm{A}$ & & & & \\
\hline
\end{tabular}

\subsection{Impact comparison}

The joint consideration of all the alterations or impacts generated by the light rail system, which is known as the Global Environmental Impact, represents the final filter for its environmental justification. This impact should be compared with those of all the other solutions considered to solve the mobility problem.

Thus, as a complement to this Identification Matrix, we developed a direct comparison of the positive and negative effects of the light rail implementation with respect to the current systems of transportation of workers (and tourists) using buses. It is important to note that, for the current bus system, we 
considered as indispensable the repaving of the existing road, since it would not be able to provide a sufficient degree of service to the amounts of workers and tourists expected in the cayos over the next few years.

In the comparison, the main advantages of the light rail system are:

Lower transfer times

- Less accidents and higher levels of safety

- Smaller energy consumption per person transported

- Zero or low degree of pollutant emission

- Lower noise levels

- Higher levels of comfort

- Excess capacity that can be used for tourist transportation

- Better overall image of the transportation service

- Lager transport capacity

- Right of way in intersections

- Reduction of overall traffic congestion in the road and pedraplén

On the other hand, the main disadvantages of light rail with respect to buses are:

- It requires high structural stability of the pedraplén in order to allow for train sustentation and vibrations

- Higher visual impact

- Lower service frequencies for a given demand

- Need to incorporate new infrastructure in case of service extension

- Lower accessibility, which requires transfers. Possibility of longer overall displacement times.

- Longer implementation period

- Reduction of the available space for vehicles and pedestrians

- Possible safety implications

As a result, the advantages of the light rail system cannot be assumed to clearly outperform the disadvantages. The implementation required a series of preventive and corrective measures which minimized of eliminated these disadvantages and the corresponding impacts identified in Table 3. The following section describes the measures that were suggested for this particular project.

\section{Preventive and corrective measures}

For each negative impact of the light rail system to the cayos, we describe here the measures or actions that help minimize it [5]:

Impact \#1: Noise emissions during the construction phase

Actions: - Use low-noise equipment

- Adjust the schedule of construction works so as to minimize the impact on the population

- Arrange detours avoiding residential areas

- Avoid works during weekends or tourist high seasons 
Impact \#2: Powder emissions during the construction phase

Actions: - Water unpaved machinery trails and areas once a day

- Install lateral protections to retain particulate materials

- Wet arid materials during loading, unloading, transportation and storage operations

- Unload materials from heights lower than $1 \mathrm{~m}$. when possible

- Cover storage heaps

Impact \#3: Generation of acoustic emissions during the exploitation phase

Actions: - Avoid low turning radiuses and steep slopes

- Speed control

- Design the infrastructure incorporating ballasting structures, elastic rail bearings, insulation screens, etc.

- Use cars with disk brakes, elastic wheel bands, noise absorbents, anti-vibration structure, etc.

- Adequate machinery maintenance

Impact \#4: Reduction of the available space for vehicles and pedestrians

Actions: - Reduce the width of road lanes

- Increase the width of the roadbed by the acquisition of additional land

- Redesign crossings to increase operational efficiency and safety

Impact \#5: Possible safety implications

Actions: - Visual and acoustic signaling in shared platform areas

- Increase precautions in the design of transfer points and stations

- Guarantee preventive maintenance

- Professional training of drivers and operators

- Appropriate and frequent medical monitoring of personnel

Impact \#6: Water pollution

Actions: - Locate oil and waste containers at least $30 \mathrm{~m}$. away from water courses

Impact \#7: Higher visual impact

Actions: - Limit the height of infrastructures as much as possible

- Install visual screens close to urban areas, using natural elements

- Keep the work area clean during the construction phase

Impact \#8: Lack of knowledge on environmental laws and regulations for preserved areas

Actions: - Generate, apply and monitor environmental plans

- Implement an environmental strategy to integrate touristic development in extremely fragile ecosystems

- Create a public infrastructure specialized in environmental issues, which enforces an adequate level of protection 
Impact \#9: Water runoffs

Actions: - Build settling basins, infiltration ditches, artificial humid soils, course channelling, etc.

Besides these actions, an environmental impact analysis should also include an environmental monitoring programme to control the evolution of impacts and the efficacy of corrective measures. The impacts identified in the previous section and the prophylactic measures proposed here should be under scrutiny during the construction phase and over the first few years of exploitation in order to guarantee the soundness of the initial estimations and prevent the excessive alteration of any sustainability parameter.

\section{Shuttle service for workers}

The fact that the light rail system presents lower accessibility (in terms of doorto-door service) than buses, with the extension of the existing railroad planned only until the main roundabout in Cayo Coco, results in the need for an additional shuttle bus service to transfer the workers (and tourists) arriving by train to the hotels in Cayo Coco and Cayo Guillermo. However, sustainability policies require that shuttle service to be provided by the minimum number of vehicles, covering the minimum possible distances and thus consuming the minimum amount of energy.

We built an optimization model to minimize the number of required buses, starting from the existing fleet described in Table 1, and the distances to be covered by them when transferring the workers from the Cayo Coco roundabout to their hotels. The model is built on a graph with n nodes, where the base node $i=0$ corresponds to the Cayo Coco roundabout and the rest to the different hotels, and the available bus fleet is assumed to be the one described in Table 1. The model contains the binary variables $y_{i k}$ to represent whether hotel $i$ is served by bus $k$, and $\delta_{k}$ to represent whether bus $k$ is used for the shuttle service, and the integer variables $x_{i k}$, which account for the number of workers transported to hotel $i$ in bus $k$. With respect to the data, $c_{i}$ is equal to the distance between hotel $i$ and the base node; $d_{i}=2 \cdot c_{i} ; c_{s}$ is equal to the distance between the base node and the hotel areas $\left(c_{s}=4 \mathrm{~km}\right.$ for Cayo Coco and $34 \mathrm{~km}$ for Cayo Guillermo, see Figure 2); $b_{k}$ is the capacity of bus $k ; a_{i}$ is the number of workers of hotel $i$; and $C$ is the fixed cost (in distance units) of using an additional vehicle in the fleet. The model is as follows:

$$
\begin{array}{lc}
\text { Min } & \sum_{k} \sum_{i} d_{i} y_{i k}-\sum_{k} 2 c_{s}\left[\sum_{i} y_{i k}-1\right]+C \sum_{k} \delta_{k}-\sum_{k} 2 c_{s}\left(1-\delta_{k}\right) \\
\text { s. } & \sum_{k} y_{i k} \geq 1 \quad \forall i=1, \ldots, n
\end{array}
$$




$$
\begin{gathered}
y_{i k} \leq \delta_{k} \quad \forall i=0,1, \ldots, n ; k=1, \ldots, K \\
x_{i k} \leq y_{i k} b_{k} \quad \forall i=0,1, \ldots, n ; k=1, \ldots, K \\
\sum_{i} x_{i k} \leq b_{k} \quad \forall k=1, \ldots, K \\
\sum_{k} x_{i k}=a_{i} \quad \forall i=0,1, \ldots, n \\
y_{i k}, \delta_{k} \in\{0,1\} ; x_{i k} \text { integer }
\end{gathered}
$$

The objective function (1) minimizes the number of buses used in the fleet and the total distance covered by them in their daily services. The first term calculates this total distance, but the second term subtracts the savings generated when the same bus services two hotels in the same trip; the third term penalizes the use of additional buses, and the fourth one eliminates the savings for those buses that were not used at all. With respect to restrictions, (2) forces all hotels to be serviced; (3) ensures that only used buses can service hotels; (4) imposes that only those buses servicing a given hotel may transport workers to that hotel, and (5) ensures that the amount of workers transported is limited by the bus' capacity; (6) is the demand restriction, and (7) describe the feasible values that can be taken by the different variables.

We solved the model using the gplk toolbox in Matlab. We solved two different models, one for Cayo Coco and another for Cayo Guillermo, given the characteristics of the graph and the fact that buses would either serve one hotel are or the other, but never both at the same time. We also solved separate models for high, medium and low season. The results are shown in Table 5.

Table 5: Number of buses needed to provide shuttle service from the Cayo Coco roundabout to the hotels.

\begin{tabular}{|c|c|c|}
\hline Season & Cayo Coco & Cayo Guillermo \\
\hline High & 13 buses seating 45 & 1 bus seating 52 and 2 buses seating 45 \\
\hline Medium & 16 buses seating 45 & 2 buses seating 52 and 1 bus seating 45 \\
\hline Low & 19 buses seating 45 & 3 buses seating 52 and 1 bus seating 45 \\
\hline
\end{tabular}

Additional buses should be used for the other destinations shown in Table 6 .

Adding up the figures, the optimal fleet size for the shuttle service should include 6 buses seating 52 and 35 buses seating 45, which represents a significant reduction with respect to the current values. 
Table 6: Additional buses for other shuttle services.

\begin{tabular}{|c|c|c|c|c|}
\hline & \multicolumn{3}{|c|}{ Season } \\
\hline & & Low & Medium & High \\
\hline \multirow{2}{*}{$\begin{array}{l}\text { Cayo } \\
\text { Coco }\end{array}$} & $\begin{array}{c}\text { Airport and } \\
\text { Customs office }\end{array}$ & 4 seating 52 & $\begin{array}{l}2 \text { seating } 52 \\
3 \text { seating } 45\end{array}$ & $\begin{array}{l}2 \text { seating } 52 \\
4 \text { seating } 45\end{array}$ \\
\hline & $\begin{array}{c}\text { Non-hotel } \\
\text { destinations }\end{array}$ & 6 seating 45 & $\begin{array}{l}1 \text { seating } 52 \\
6 \text { seating } 45\end{array}$ & 9 seating 45 \\
\hline \multirow{2}{*}{$\begin{array}{c}\text { Cayo } \\
\text { Guillermo }\end{array}$} & Caracol & 1 seating 45 & 1 seating 52 & 2 seating 45 \\
\hline & Marina Port & 1 seating 45 & 1 seating 45 & 1 seating 52 \\
\hline
\end{tabular}

\section{Conclusions}

After completing the analysis, a series of conclusions may be extracted from it. In the first place, we can conclude that the light rail system constitutes a sound and adequate solution for the commuting of workers to the hotels in the cayos. This was one of the best solutions selected from the economic point of view, and it has also proved environmentally sustainable, since its benefits outweigh its drawbacks, and the latter can be reduced or eliminated through the appropriate set of measures. This is a very important fact, due to the need to preserve the high environmental and landscape value of the area, whose increasing touristic development is precisely due to it. It is however this increase in touristic demand was will eventually render the bus system unsustainable.

The light rail system would then generate economies of scale not only economically but also environmentally, solving many of the pollution problems linked to the operation of the current bus fleet. Still, the use of buses is required to provide a shuttle service from the rail terminal, located in the main roundabout of Cayo Coco, and the hotels, which are between 4 and $34 \mathrm{~km}$. away. In order to provide this service at the minimum economic and environmental cost, we built an optimization model to determine the size of the minimum fleet required to provide this service in low, medium and high season.

With respect to the future, if the growth in the area continues at the same rhythm and the light rail system to the Cayo Coco roundabout proves efficient, the possibility should be contemplated to extend the railroad until Cayo Guillermo. This would further reduce the number of buses used inside the cayos, thus also reducing their environmental impact and allowing for the sustainable development of the smaller island.

\section{References}

[1] Muñuzuri, J., Cortés, P., Onieva, L. and Guadix, J. (2007) How should workers be transported to a developing hotel area in Cuba? International Journal of Tourism Policy, 1(3), 232-245.

[2] Klingenberg, H. (1996) Automobile exhaust emission testing. Springer.

[3] García, A., Cillero, A. and Rodríguez, P. (1998) Operación de trenes de viajeros. Fundación de los Ferrocarriles Españoles, Madrid. 
26 Island Sustainability II

[4] Español, I. (1995) Impacto Ambiental. ETS Ingenieros de Caminos, Canales y Puertos, Madrid.

[5] Tiktin, J. (1998) Medidas correctoras del impacto ambiental en las infraestructuras lineales. E.T.S. Ingenieros de Caminos, Canales y Puertos, Madrid. 